\title{
Role of Ideological and Political Education in Career Education of College Students
}

\author{
Min Fan \\ Physical Education Department, Xi'an Physical Education University, \\ Xi'an, 710068, China
}

Keywords: college students; career education; ideological and political education; role

\begin{abstract}
Currently, more and more people pay high attention to career education of college students. Ideological and political education becomes a vital constituent part of career planning education and plays a vital role in the implementation of career education of college students. This paper analyzes the status of the current ideological and political education of college students, describes the urgency of including career education of college students in ideological and political education and discusses the role of ideological and political education in promoting career education of college students.
\end{abstract}

\section{Introduction}

Under the current background of popularization of higher education, the social demand for undergraduate talents and employment consciousness of college students present a new trend of diversification. Currently, college graduates are facing increasingly severe employment competition. They care more about their future and pay more attention to their career planning. This brings new challenge to ideological and political education of institutions of higher learning. To comply with the development of the current situation, colleges and universities should strengthen career planning education of college students and improve the pertinence of ideological and political education practically. Career planning mainly aims at pursuing all-round development of people and is an important manifestation of people-oriented thought. Career education of college students should be close to their actual thoughts so as to meet their subjective demands and present the feature of concretization of ideological and political education in institutions of higher learning. On that account, ideological and political education of institutions of higher learning must include career education as a new content and give full play to the outstanding function of ideological and political education so as to meet social demands for talents and students' development needs.

\section{Analysis on status of current ideological and political education of college students}

Ideological and political education of college students in the traditional sense often remains at the level of mechanical explanation with the lack of effectiveness and a lot of repetition. Moreover, it emphasizes implantation and coerciveness a lot. Therefore, the ideological and political work in many colleges and universities is superficial. However, after completing the four-year study in colleges and universities, college students finally will take a post and realize the transition from student to social man. The transition from the career as college students to professional career seems logical. However, it cannot separate from the constant accumulation of abilities of college students or the influence of ideological and political education. Under the guidance of ideological and political education, college students should not only complete self-perception, but also complete the training of many abilities and seamless joint with labor market so as to give full play to their energy. Currently, the increasingly severe employment situation of college graduates not only proves difficult employment caused by enrollment expansion of colleges and universities, but also demonstrates the reality that talents trained in colleges and universities and social demands are not equal. To actually reverse the situation and make ideological and political education of college students obtain good effect, it is required to find out actual demands of college students and trigger their positive emotional experience and ideological resonance in the way of education. This requires 
integrating new contents and finding out new thought in ideological and political education of college students.

\section{Urgency of including ideological and political education in career education of college students}

Ideological and political education of college students is an important content maintaining the stability of colleges and the society. How to implement ideological and political education of college students becomes a hot spot arousing great attention in the whole society. The author thinks that the main trend of thought of contemporary college students is positive and they have active thought, enterprising spirit, ideal and rich pursuit. However, it is required to realize clearly that some college students have many negative thoughts under the influence of various negative factors. The occurrence of such negative thoughts is caused by bad influence of social environment and family and, more importantly, the lack of career education. A lot of students fail to realize their career orientation clearly after entering colleges and universities. Therefore, they often lack clear and scientific job objective and feel vacant. Moreover, under the new situation of severe employment competition, they easily give up when facing difficulties in career choice and development. Unsmooth employment of college graduates will pose a big pressure on family and society. Therefore, it is required to spare no effort to explore and form a new management mechanism with interrelation between social practice and professional learning, social service, work-study program and job selection and employment.

\section{Role of ideological and political education in promoting career education of college students}

With the constant deepening of reform and opening up in China currently, college students easily deviate from the correct development direction in the process of constant integration of economy and culture as their thought is not mature and they are easily tempted by various interests. Therefore, they change their career objectives very frequently, lack a relatively steady development way, pursue for utilitarianism and commercialization one-sidedly in career choice and deviate from their own orientation, which is adverse to the implementation of career education of college students. On that account, it is required to actually ensure that career education of college students can realize benign development in the correct direction through the implementation of systematic ideological and political education. How to give better play to the function of promotion of ideological and political education seems extremely important.

(I) Objectives of ideological and political education can ensure the correct development direction of career education of college students

Considering objectives of ideological and political education of institutions of higher learning, the ultimate goal of ideological and political education is to improve the overall ideological and moral quality and scientific and cultural quality of the Chinese nation and the corresponding ability of college students in understanding and changing the world so as to mobilize employees to make continuous efforts to realize the great Chinese dream and ideal of communism. Through the implementation of effective ideological and political education, institutions of higher learning can help college students to implement rational career education in a planned and conscious way according to requirements put forward by the society so as to improve the comprehensive quality of college students practically and realize all-round development of undergraduate talents.

(II) Contents of ideological and political education can be conducive to the shaping of comprehensive quality of undergraduate talents

First, it is required to go deep into the implementation of education in world outlook, outlook on life and value and help college students to establish a correct professional idea, correct their attitude towards life and implement rational career orientation. Social development demands are objective requirements for taking an ideal post. One of the important objectives of ideological and political education of institutions of higher learning is to train ideological and moral quality of educatees consciously and continuously through schools and the society according to social demands and 
further promote all-round development of undergraduate talents. From this point of view, ideological and political education can help college students form a clear professional ideal and fully combine individual ambition with national interests and social demands. Meanwhile, students should define their own career objectives. Ideological and political education can allow college students to see the relationship between personal interests and national interests in the learning process through the implementation of debate and lecture activities. We can also use network to positively guide college students to use network reasonably to obtain relevant knowledge and help college students establish a correct outlook on life, treat contradictions between ideal and reality and individuals and society rationally and resist the impact and temptation of money worship tendency in market economy and decadent ideas from network or the west consciously.

Second, the education of awareness of unexpected development and spirit of hard struggle in ideological and political education of college students can help college students inherit and promote good tradition. The increasingly severe competition in market economy increases employment difficulty. In particular, current college graduates need to face international talent competition. Therefore, it is required to strengthen the education of awareness of unexpected development and spirit of hard struggle of college students in the process of career education. They can effectively help college students to make accurate self-analysis and career analysis, correctly see their own advantages and disadvantages and maintain a healthy and positive attitude. Meanwhile, it is required to guide college students to understand and handle problems encountered in the development path correctly and train their good moral integrity and positive psychological quality. For example, college students should treat setbacks in job selection correctly and train good psychological quality of being bold in and good at competition. In the process of career education of college students, it is necessary to guide students to accumulate knowledge in various aspects according to sustainable development requirements of career and society positively, implement more scientific and rational reconstruction, form rational knowledge structure and reflect the overall efficiency of knowledge to the greatest extent. This requires undergraduate talents to promote the spirit of hard struggle better. In the process of implementing ideological and political education, it is required to not only carry out educational activities according to learning objectives, help college students to establish more rational teaching objectives and include social demands in career education of college students, but also be committed to implementing professional ideological and political education and stabilizing the professional idea of college students practically.

Third, it is required to strengthen the training of subject consciousness and education of cooperative consciousness, which is conducive to realizing mutual unification between independence and cooperativeness of undergraduate talents. The implementation of career education should allow college students to have more independent thought and abilities of solving various problems independently. Ideological and political workers in institutions of higher learning should not only create rational environmental conditions for independent thought of college students, but also implement career planning education consciously and prevent college students from emphasizing individualism too much. The implementation of ideological and political education can strengthen the training of practical ability of college students, organize them in participating in relevant professional training better and train their cooperative awareness consciously and purposefully by carrying out collective activities and classroom discussion etc.

Forth, it is required to implement guiding professional ethics education and legal education and impel college students to transition into professional man. In allusion to the lack of honesty in the current society, it is very necessary to implement guiding professional ethics education and legal education. Institutions of higher learning can use career guidance course to allow college students to understand professional ethic requirements that a professional man should meet in the future, have preparation in knowledge and skills and good psychological preparation in professional moral rule after entering the society, use rational value to treat their own career choice, strictly abide by national laws and regulations and perform their democratic rights correctly. 


\section{(III) The method of individualized teaching in ideological and political education can strengthen the effectiveness of career design of college students}

Ideological and political education of college students require educators to conduct equal communication with educatees as equal participant and communicator and allow college students to correct their shortcomings and give play to their advantages more consciously instead of expounding something mechanically in a commanding position. Meanwhile, ideological and political education of institutions of higher learning should maintain a reasonable tension between individuals demanding and meeting demands. That is to say, educators should put forward corresponding requirements for college students according to current social demands, the order of priority of education implementation and individual potential and respect and meet interests, demands and will of individual development of college students to the greatest extent based on rational development objectives. The implementation of individualized teaching method mainly aims at training various kinds of talents at different levels in the new situation. It is necessary to implement ideological and political education according to undergraduate talents' characteristics of seeking knowledge, truth and personality development. Considering that college students in the generation after 90s have the distinct feature of strong self-awareness, it is impossible to distinguish them with the boundary of advanced or backward nature. Features above cause local college students to have complicated individualized differences in ideological consciousness and moral level. Therefore, it is required to implement ideological and political education in a more flexible way in allusion to college students' differences in personality. Career education of each college student will be different due to personality differences. This requires implementing ideological and political education according to different grades and age. For example, freshmen are in the adaptive phase and their task is to plan their career rationally. Sophomores are in the exploration stage and their task focuses on the training of basic abilities and comprehensive quality. Junior students are in the period of struggle and their task is to implement career guidance. Senior students are in the spring period and their task is to implement employment guidance. The effectiveness of ideological and political education can be revealed in this way.

\section{Conclusion}

In conclusion, career education of college students is a long-term systematic project, which provides new direction for better implementation of ideological and political education of college students. Career planning of college students must take ideological reality and growth needs of undergraduate talents as opportunity, fully excavate their potentials and mobilize their subjective initiative in learning. In ideological and political education practice, it is required to excavate the function of ideological and political education in career planning of college students, continue to improve various measures of career planning of college students and actually improve the effectiveness of ideological and political education of college students.

\section{References:}

[1] Hu Kai. Discussions on Status and Role of Career Education in Ideological and Political Education of Colleges and Universities [J]. Studies in Ideological Education, 2012(1).

[2] Zhou Hong. Research on Integration of Ideological and Political Education and Career Education in Colleges and Universities [J]. Heilongjiang Higher Education Research, 2012(3).

[3] Cui Huifang. Three Stages of Career Education: Explore Effective Carrier of Ideological and Political Education of Students in Higher Vocational and Technical Colleges [J]. Contemporary Educational Theory and Practice, 2012(7).

[4] Chen Xiaodong. Brief Discussions on Significance of Career Planning of College Students for Ideological and Political Education [J]. Journal of Changchun Finance College, 2013(1).

[5] Jing Yuxia. Discussions on Efficient Way of Combining Career Planning Education and Ideological and Political Education of College Students [J]. Jiangsu Education Research, 2013(18).

[6] Hao Yuanyuan. Discussions on Organic Integration of Ideological and Political Education and 
Career Education of College Students [J]. Youth and Juvenile Research (Journal of Shandong Youth League School), 2014(1). 